\title{
Hubungan Facial Injury Severity Scale dengan lama rawat inap pasien trauma maksilofasial di RSUP Prof. Dr R. D. Kandou Manado
}

\author{
${ }^{1}$ Richard Rampisela, ${ }^{2}$ Nico Lumintang, ${ }^{3}$ Jan T. Ngantung
}

\author{
${ }^{1}$ PPDS Ilmu Bedah Umum Fakultas Kedokteran Universitas Sam Ratulangi Manado \\ ${ }^{2}$ KSM Bagian Bedah Kepala Leher RSUP Prof. Dr. R. D. Kandou Manado \\ ${ }^{3}$ Bagian Ilmu Bedah Fakultas Kedokteran Universitas Sam Ratulangi Manado \\ Email: richard.rampisela@gmail.com
}

\begin{abstract}
Maxillofacial trauma includes soft tissue injuries, such as burns, bruises and contusions, as well as fractures of facial bones that form the maxillofacial structure. The causes of maxillofacial fractures are traffic accidents, falls, hits, gun shots, sport accidents, and industrial accidents. Scoring system has been introduced as a tool to determine the prognostic value of patients with trauma. Facial trauma requires a different scoring system due to many dysfunctions that can occur afterwards. This study was aimed to determine the length of stay (LOS) of inpatients by using Facial injury Severity Scale (FISS). This was a correlation analytical study with a cross sectional design performed on inpatients of emergency care installation and medical records at Prof. Dr. R. D. Kandou Hospital from January 2015 through April 2016. The results showed that there were 52 patients in this study. Most of them were males (49 cases; $94.2 \%$ ), aged $17-25$ years (16 cases; $30.8 \%$ ), refused to be operated (40 cases; 76.9\%), patients with FISS 1-3 (42 cases; 80.7\%), minor trauma (FISS <3), and zygoma fracture cases. The Pearson correlation coefficient test showed an $r$ value $=0.646(P<0.001)$ which stated that there was a significant relationship between FISS and LOS. Conclusion: Most patients with maxillofacial trauma had a FISS value less than 3 (mild trauma). Moreover, this FISS value could be used to estimate the length of stay.
\end{abstract}

Keywords: maxillofacial trauma, facial fractures, FISS

\begin{abstract}
Trauma maksilofasial mencakup cedera jaringan lunak seperti luka bakar, mencakup cedera jaringan lunak seperti luka bakar, memar, fraktur tulang fasial yang membentuk sturktur maksilofasial. Penyebab fraktur maksiofasial ialah antara lain kecelakaan lalu lintas, jatuh, pukulan, tembakan, kecelakaan olah raga, dan kecelakaan kerja. Sistem skoring digunakan untuk menentukan nilai prognostik pasien dengan trauma. Trauma fasial memerlukan sistem skoring yang berbeda karena banyak disfungsi yang dapat terjadi. Penelitian ini bertujuan untuk menentukan lama rawat inap dari pasien cedera fasial dengan menggunakan Facial injury Severity Scale (FISS). Jenis penelitian ialah korelasi analitik dengan desain potong lintang terhadap pasien rawat ianap dengan trauma maksilofasial di Instalasi Gawat Darurat dan Bagian Rekam Medik RSUP Prof. Dr. R. D. Kandou periode Januari $2015 \mathrm{~s} / \mathrm{d}$ April 2016. Hasil penelitian mendapatkan 52 pasien dengan trauma maksilofasial. Sebagian besar pasien ialah laki-laki (49 kasus; 94,2\%), berusia 17-25 tahun (16 kasus; 30,8\%), menolak dioperasi (40 kasus; 76,9\%), nilai FISS 1-3 (42 kasus; 80,7\%), trauma ringan (FISS <3), dan fraktur tulang zygoma. Uji korelasi Pearson mendapatkan nilai $r=0,646$ $(P<0,001)$ yang menunjukkan terdapatnya hubungan bermakna antara FISS dan lama rawat inap. Simpulan: Umumnya pasien dengan trauma maksilofasial mempunyai nilai FISS 3 (trauma ringan). FISS mempunyai nilai prognostik terhadap lama rawat inap.
\end{abstract}

Kata kunci: trauma maksilofasial, fraktur fasial, FISS 
Cedera pada maksilofasial dapat merupakan cedera tunggal atau dapat bersamasama dengan cedera pada kepala, dada, perut, tulang belakang, dan anggota gerak. Sekitar 70\% kecelakaan lalu lintas (KLL) disertai trauma pada kepala dan leher, dan yang paling sering mengalami cedera ialah bagian maksilofasial, terutama tulang rahang bawah. ${ }^{1-4}$

Penyebab cedera maksilofasial baik di berbagai daerah maupun negara bervariasi tergantung kondisi sosial-ekonomi, budaya, dan faktor lingkungan. Penyebab paling sering patah tulang maksilofasial di dunia ialah KLL, terjatuh, dipukul, senjata api, olahraga, dan kecelakaan industri. KLL dilaporkan merupakan penyebab utama patah tulang maksilofasial di negara berkembang. Insiden trauma maksilofasial akibat KLL sangat bervariasi dan sekitar $22 \%$ dilaporkan terjadi di negara maju. ${ }^{1,3,5-7}$

Trauma maksilofasial mengakibatkan jejas dan kegawatan dengan variasi yang sangat luas, mulai memar, eksoriasi, serta berbagai jenis vulnus pada jaringan lunak sampai patah tulang. Patah tulang pada maksilofasial bisa terjadi hanya pada satu tempat ataupun kompleks, akibat benturan dengan kekuatan rendah atau akibat kekuatan tinggi. ${ }^{1,8}$

Sistem penilaian telah muncul sejak tahun 1970-an untuk mengukur tingkat keparahan pada pasien, khususnya pasien trauma. Sistem penilaian ini bertujuan mencari nilai prognostik untuk pasien trauma agar menjadi alat ukur dalam penelitian. Awalnya, sebagian besar sistem penilaian hanya mengevaluasi trauma pada umumnya, seperti Injury Severity Score (ISS), Trauma and Injury Severity Score (TRISS), dan New Injury Severity Score (NISS). Sistem mencetak diyakini memiliki nilai prediktif pada pasien trauma. Beberapa dari mereka mampu dikombinasikan skor cedera sebelumnya dengan parameter fungsional wajah, seperti Maxillofacial Injury Severity Score (MFISS) dan Mandible Injury Severity Score (MISS). ${ }^{9-11}$

Sistem penilaian lainnya dibuat sederhana namun terbukti memiliki nilai prediktif, seperti Facial Injury Severity Scale (FISS) dan Chinese Maxillofacial Trauma Registry, Analysis and Injury Severity Score System (CMISS). ${ }^{9,10,12}$ FISS diperkenalkan oleh Bagheri di Jurnal Oral Maksilofasial Bedah 2006. Dalam sistem penilaian ini, setiap situs fraktur dan luka gores di wajah akan menambah poin untuk mendapatkan skor akhir. Bagheri, dengan total 247 pasien di ruang kerjanya, juga menemukan FISS memiliki korelasi dengan biaya total operasi dan lama tinggal. ${ }^{9,11,13}$

Sistem skoring telah diperkenalkan sebagai alat untuk mencari nilai prognosis pada pasien trauma. Trauma wajah memerlukan sistem skoring yang berbeda karena banyak gangguan fungsi yang bisa ditimbulkan. Beberapa jurnal telah melaporkan adanya sistem skoring untuk trauma maksilofasial seperti Skor Facial Injury Severity Scale (FISS) dan Maxillofacial Injury Severity Score (MFISS). ${ }^{9,11.14}$

\section{METODE PENELITIAN}

Jenis penelitian ini ialah analitik korelatif dengan desain potong lintang yang bertempat di IRDB dan Bagian Rekam Medik RSUP Prof. Dr. R. D. Kandou Manado. Populasi penelitian ini ialah seluruh pasien trauma yang masuk ke Unit Gawat Darurat Rumah Sakit yang dirawat pada periode Januari 2015-April 2016.

Data populasi dikumpulkan berdasarkan catatan status semua penderita yang didiagnosis sebagai kasus trauma maksilofasial termasuk cedera jaringan lunak yang memenuhi kriteria inklusi. Penghitungan subyek penelitian dipilih berdasarkan permasalahan hubungan 2 kelompok. Kriteria inklusi penelitian ialah seluruh pasien trauma maksilofasial termasuk cedera jaringan lunak yang dibuktikan dengan CT scan 3D /Photo Skull AP/Lateral/Waters akibat KLL, trauma maksilofasial termasuk cedera jaringan lunak tanpa adanya kelainan organ lain, bersedia menjalani pemeriksaan fisik dan radiologik terhadap cedera yang diderita pada kepala dan wajah, serta menandatangani persetujuan menjadi 
subyek penelitian. Kriteria eksklusi ialah penderita dengan fraktur tulang wajah dan cedera jaringan lunak disertai cedera organ lain dan adanya penyakit penyerta

Data dikelompokkan berdasarkan variabel penelitian kemudian disajikan dalam bentuk teks dan tabel, selanjutnya dianalisis berdasarkan persentase. Data yang diperoleh ditabulasi dan diuji kemaknaannya dengan analisis regresi linier sederhana dan koefisien korelasi Pearson.

\section{HASIL PENELITIAN DAN BAHASAN}

Jenis penelitian ini ialah deskriptif analitik dengan desain potong lintang. Penelitian dilakukan pada pasien trauma maksilofasial yang datang di IRDB dan data rekam medis RSUP Prof Dr. R. D. Kandou Manado dari yang memenuhi kriteria inklusi selama periode Januari 2015-April 2016 sebanyak 52 kasus trauma maksilofasial akibat kecelakaan lalu lintas.

Tabel 1 memperlihatkan dari 52 kasus, laki laki yang paling banyak mengalami trauma maksilofasial berjumlah 49 kasus $(94,2 \%)$ dibandingkan dengan perempuan berjumlah 3 kasus $(5,8 \%)$. Hal ini sesuai dengan beberapa acuan pustaka yang menyatakan bahwa laki-laki lebih banyak dibandingkan perempuan yang menderita trauma. Chalya et al. ${ }^{1}$ melaporkan bahwa laki-laki berisiko tinggi mengalami trauma karena banyaknya kegiatan dengan risiko tinggi seperti mengendarai mobil/motor, olahraga dengan kontak fisik, kehidupan sosial aktif, dan penggunaan obat termasuk alkohol.

Tabel 1. Distribusi penderita menurut jenis kelamin

\begin{tabular}{ccc}
\hline Jenis kelamin & Frekuensi & \% \\
\hline Laki-Laki & 49 & 94,2 \\
Perempuan & 3 & 5,8 \\
Total & 52 & 100,0 \\
\hline
\end{tabular}

Tabel 2 menunjukkan bahwa penderita yang mengalami trauma maksilofasial berusia 9 tahun s/d 71 tahun, dan yang terbanyak pada usia $17-25$ tahun $(30,8 \%)$. Hasil ini selaras dengan beberapa penelitian lain seperti yang dilakukan oleh Akhigbe di Nigeria dan Kraft et al. ${ }^{15}$ di Innsbruck. Hal ini disebabkan karena pada usia tersebut banyak masyarakat yang aktif berkendara termasuk yang baru belajar mengemudi, serta adanya keterlibatan alkohol.

Tabel 2. Distribusi penderita menurut usia

\begin{tabular}{ccc}
\hline Usia (Tahun) & Frekuensi & Persentase $(\%)$ \\
\hline $5-11$ & 3 & 5,8 \\
$12-16$ & 6 & 11,5 \\
$17-25$ & 16 & 30,8 \\
$26-35$ & 11 & 21,2 \\
$36-45$ & 6 & 11,5 \\
$46-55$ & 4 & 7,7 \\
$56-65$ & 5 & 9,6 \\
$>65$ & 1 & 1,9 \\
Total & 52 & 100 \\
\hline
\end{tabular}

Tabel 3 memperlihatkan bahwa bahwa umumnya kasus trauma maksilofasial yang dirawat menolak untuk dilakukan tindakan bedah yaitu sebanyak 40 kasus $(76,9 \%)$ pada 7 kasus $(13,5 \%)$ dilakukan tindakan konservatif; dan pada 5 kasus $(9,6 \%)$ dilakukan tindakan bedah. Hal ini selaras dengan penelitian Rothman et al. ${ }^{16}$ terhadap pasien usia lanjut dengan penyakit kronis yang menyatakan bahwa penyebab penolakan operasi disebabkan karena berbagai alasan antara lain karena takut adanya efek samping dan tidak adanya asuransi.

Tabel 3. Distribusi penderita menurut tindakan

\begin{tabular}{ccc}
\hline Tindakan & Frekuensi & \% \\
\hline Konservatif & 7 & 13,5 \\
Menolak & 40 & 76,9 \\
Operasi & 5 & 9,6 \\
Total & 52 & 100,0 \\
\hline
\end{tabular}

Tabel 4 menunjukkan bahwa pasien trauma maksilofasial yang masuk ke RSUP 
Prof. Dr. R. D .Kandou dengan nilai FISS terbanyak antara 1-3 dengan jumlah 42 kasus; nilai 4-6 dengan 8 kasus; dan nilai $\geq 7$ dengan 2 kasus. Yamamoto et al. ${ }^{17}$ meneliti 320 pasien dengan fraktur midfasial di Nara, Jepang serta Kesuma dan Bangun $^{10}$ di RS Cipto Mangunkusumo Jakarta mendapatkan umumnya trauma maksilofasial dengan nilai FISS dibawah 3 menunjukkan trauma ringan (mild).

Tabel 4. Nilai FISS dan lama rawat

\begin{tabular}{cccc}
\hline No & FISS & $\begin{array}{c}\text { Jumlah } \\
(\mathbf{N})\end{array}$ & $\begin{array}{c}\text { Lama rawat } \\
(\text { rerata) }\end{array}$ \\
\hline 1 & $1-3$ & 42 & 4,8 hari \\
2 & $4-6$ & 8 & 8,6 hari \\
3 & $\geq 7$ & 2 & 10 hari \\
\hline
\end{tabular}

Dalam penelitian ini tingkat keparahan trauma ialah trauma ringan dengan FISS terbanyak <3 dan kasus terbanyak ialah fraktur tulang zygoma. Rerata lama rawat inap pasien berdasarkan nilai FISS (Tabel 4) yaitu: nilai FISS 1-3 selama 4,8 hari; FISS 4-6 selama 8,6 hari; dan FISS $\geq 7$ selama 10 hari. Makin rendah nilai FISS makin pendek lama rawat sedangkan makin tinggi nilai FISS maka makin lama rawat inapnya. Penelitian Ramalingan ${ }^{9}$ di India Smith $^{18}$ di Iowa mendapatkan umumnya lama rawat inap selama 2-8 hari dengan rerata 4 hari.

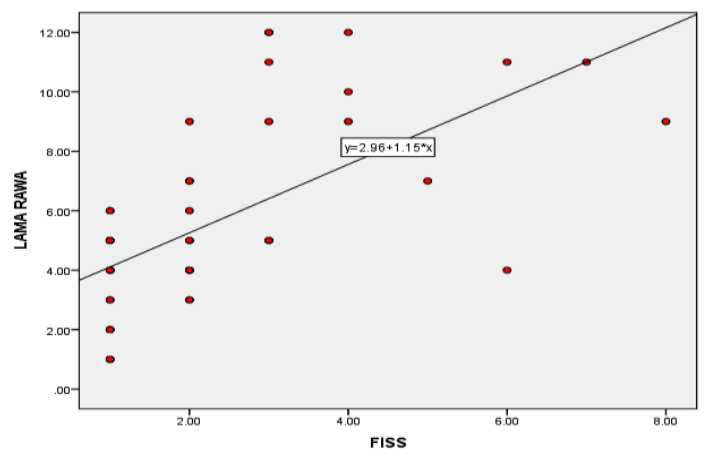

Gambar 1. Grafik hubungan Facial Injury Severity Scale dan lama rawat inap

Hasil analisis statistik menggunakan koefisien korelasi Pearson mendapatkan nilai $\mathrm{r}=0,646$ dengan $P<0,001$ (Gambar
1) yang menyatakan terdapat hubungan bermakna antara FISS dan lama rawat inap pasien trauma maksilofasial di RSUP Prof. Dr. R. D. Kandou Malalayang sehingga dengan menghitung FISS setiap pasien trauma maksilofasial yang masuk rumah sakit dapat diperkirakan lama rawat inap pasien tersebut.

\section{SIMPULAN}

Dari hasil penelitian terhadap pasien trauma maksilofasial di RSUP Prof Dr. R. D. Kandou dapat disimpulkan bahwa terdapat hubungan bermakna antara Facial Injury Severity Scale (FISS) dan lama rawat inap. Semakin besar nilai FISS semakin tinggi lama rawat inap. Nilai FISS terbanyak pada kasus trauma maksilofasial ialah $<3$ (trauma ringan).

\section{DAFTAR PUSTAKA}

1. Chalya PL, Mchembe M, Mabula JB, Karumnba ES, Gilyoma JM. Etiological spectrum, injury characteristics and treatment outcome of maxillofacial injuries in a Tanzanian teaching hospital. J Trauma Manag Outcomes. 2011;5:7.

2. Scheyerer MJ, Doring R, Fuchs N, Metzler P, Sprengel K, Werner CML, et al. Maxillofacial injuries in severely injured patients. J Trauma Manag Outcomes. 2015;9(4):1-9.

3. Filho MAMC, Saintrain MVdl, Dos Anjos REdS, Pinheiro SS, Cardoso LdCP, Moizan JAH, et al. Prevalence of oral and maxillofacial trauma in elders admitted to a reference hospital in Northeastern Brazil. Plos One. 2015;10(8):e0135813. doi:10.1371/journal.

4. Wijayahadi RY, Murtedjo U, Reksoprawiro S. Trauma Maksilofasial Diagnosis dan Penatalaksanaannya. Surabaya: Divisi Bedah Kepala dan Leher SMF/Laboratorium Ilmu Bedah RSU Dr. Soetomo/FK Universitas Airlangga Surabaya, 2006; p. 7-30.

5. Akhigbe OP. Motorcycle related maxillofacial injuries in a semiurban town in Nigeria: a four year review of cases in Irrua Specialist Teaching Hospital [Master Thesis]. Umea: Umea International School of Public Health; 2010.

6. Li R, Zhang R, Li W, He W. Analysis of 126 
hospitalized elder maxillofacial trauma victims in Central China. Med Oral Pathol Oral Cir Bucal. 2015;20(4):464-70.

7. Kamath RAD, Bharani S, Hammannavar R, Ingle SP, Shah AG. Maxillofacial trauma in Central Karnataka, India: an outcome of 95 cases in a regional trauma care centre. Craniomaxillofac Trauma Reconstr. 2012;5(4):197-204.

8. Pappachan B, Mohan A. Biomechanic of Cranio-Maxillofacial Trauma. J. Maxillofac. Oral Surg. 2012;11(2):224-30.

9. Ramalingan $\mathbf{S}$. Role of maxillofacial trauma scoring systems in determining the economic burden to maxillofacial trauma patients in India. J Int Oral Health. 2015; 7(4):38-43.

10. Kesuma AD, Bangun $K$. Evaluation of facial trauma severity in Cipto Mangunkusumo Hospital using FISS scoring system. Jurnal Plastik Rekonstruksi. 2012;1(2):162-5.

11. Zhang J, Zhang Y, Maaytah E, Liu ML, Zhou LD. Maxillofacial injury severity score: Proposal of a new scoring system. J Oral Maxillofac Surg. 2006;35:109-14.

12. Chen $C$, Zhang Y, An J, He Y, Gong $X$. Comparative study of four maxillofacial trauma scoring system and expert score. J
Oral Maxillofac Surg. 2014;35:1-16.

13. Adamo AK. Initial evaluation and management of maxillfacial injuries. $\quad \mathrm{J}$ Med. 2013;1:1-8.

14. Qiam F, Ahmad T, Wazir S, Mushtaq S, Khan M. Facial Injury Severity Scale scores amongst motorcyclists: Are they as safe as they should be. PODJ. 2016;36(2):188-91.

15. Kraft A, Abermann E, Stigler R, Zsifkovits C, Pedross F, Kloss F. Craniomaxillofacial trauma: Synopsis of 14,654 cases with 35,129 injuries in 15 years. Craniomaxillofac Trauma Reconstr. 2010;5(1):41-50.

16. Rothman MD, Van Ness PH, o'leary JR, Fried TR. Refusal of medical and surgical interventions by older persons with advanced chronic disease. J Gen Intern Med. 2007;22(7):982-7.1

17. Yamamoto $K$, Matsusue $Y$, Hortita $S$, Murakami Y, Sugiura T, Kirita T. Clinical analysis of midfacial fractures. Mater Sociomed. 2014;26(1):21-5.

18. Smith HL. Epidemiology and clinical indicators of midface fracture in patients with trauma [Dissertation]. Iowa: University of Iowa; 2011. 